\title{
CORRELATIONAL STUDY OF FINANCIAL LITERACY ON LOAN REPAYMENT OF SMALL AND MEDIUM ENTERPRISES WITHIN SACCOS IN RWANDA
}

\author{
BUMBALI Machiavel, (MBA), \\ Kibogora Polytechnic "KP" \\ PO Box 50 Nyamasheke, Rwanda \\ Website: www.kp.ac.rw \\ INGABIRE Aline, (MBA), \\ Kibogora Polytechnic "KP" \\ PO Box 50 Nyamasheke, Rwanda \\ Website: www.kp.ac.rw \\ SIBOMANA Providence, (MBA, MA), \\ Kibogora Polytechnic "KP" \\ PO Box 50 Nyamasheke, Rwanda \\ Website: www.kp.ac.rw \\ https://doi.org/10.37602/IJSSMR.2021.4403
}

\begin{abstract}
This study sought to assess the correlational influence of financial literacy on loan repayment of SMEs within SACCOs in Rwanda. The objectives were to determine how bookkeeping literacy influence loan repayment of SMEs within SACCOs, to examine how budgeting literacy affect loan repayment of SMEs within SACCOs and to assess how debt management literacy affect loan repayment of SMEs within SACCOs. Literature ascertains that access to financial literacy, budgeting literacy, and bookkeeping skills could be a potential source for the customers' ability to save, to perform better in the business, to increase their income; in short, to cater for the loan repayment.

The study adopted a descriptive quantitative research design. The total population of 130 which are SMEs were taken into consideration in its entirety. Data were analyzed using SPSS software Version 20 and presented in form of tables and graphs. The findings revealed a high positive correlation between bookkeeping, budgeting and debt management literacy and loan repayment. Moreover, R-squared was $77.2 \%$ meaning that the financial literacy factors accounted for a greater percentage of loan repayment variations. The study recommended that SACCOs should initiate more financial training to reach all members and encourage all members to attend such training. The SACCOs should also employ high qualified trainers to offer quality training to the members.
\end{abstract}

Keywords: Financial Literacy, Loan Repayment, Small and Medium Enterprises, Saving and Credit Cooperatives.

\subsection{INTRODUCTION}




\section{International Journal of Social Sciences and Management Review}

Volume: 04, Issue: 04 "July - August 2021"

ISSN 2582-0176

Financial literacy skills enable individuals to navigate the financial world, make informed decisions about their money and minimize their chances of being misled on financial matters (Beal and Delpachitra, 2005). The need for financial literacy has become significant with the deregulation of financial markets and the easier access to credit as financial institutions compete strongly with each other for market share, the rapid growth in development and marketing of financial products, and the Government's encouragement for people to take more responsibility for their retirement incomes.

Globally, financial literacy involves the understanding of both basic financial concepts and the ability and discipline to use that information to make wise personal and financial decisions. These decisions include when to spend, when to save, effectively managing a budget, choosing the right financial products and readiness to address other life events, such as financing our own or our children's education and planning for retirement. Financial literacy also helps to exercise judgment when we are offered access to credit and possessing the wisdom to understand how much is enough and how much is too much. Financial literacy is a mechanism that goes beyond political, geographic and socio-economic barriers, and it is widespread in developing countries.SMEs form more than $99 \%$ of all enterprises in the world (Capital Markets Authority, 2016).

SMEs allow the rural poor, including some of the most marginalized and vulnerable people such as women, youth, and the landless, to diversify their incomes, create new sources of economic growth and generate additional employment in rural areas. The same strata may also be reached through SME support to small-scale local entrepreneurs whose business expansion can create new jobs for the rural poor (IFAD, 2018). The global economy is heavily dependent on the success of the SME sector.

Fin Scope data, assert there is no robust relationship, but Cole, Sampson and Zia (2017) indicate an impact of a two-hour financial literacy training session in India and Indonesia. The Indonesian study, which featured a randomized field experiment, has constituted the only published experimental evaluation in a developing country thus far. Although they find no impact of the training for the entire population, they suggest that the likelihood of opening a bank account increased among the subsample of uneducated, less financially literate households.

Tustin (2016) evaluates the role of a financial literacy program on savings in Limpopo province (South Africa), using three survey questions, and finds self-reported effects of financial literacy training on saving behaviour. Landerretche and Martínez (2017) similarly find that financial literacy increases savings in private pension plans in Chile. Among the studies that examine the role of financial literacy on bank account ownership.

Tustin (2016) evaluates the role of a financial literacy program on savings in Limpopo province (South Africa), using three survey questions, and finds self-reported effects of financial literacy training on saving behaviour. Landerretche and Martínez (2019) similarly find that financial literacy increases savings in private pension plans in Chile. Among the studies that examine the role of financial literacy on bank account ownership.

Empirical studies in Kenya include that done by Wanjohi (2017) cites lack of financial skills as a major challenge on loan administration among the DTMFI (Deposit Taking 


\section{International Journal of Social Sciences and Management Review}

Volume: 04, Issue: 04 "July - August 2021"

ISSN 2582-0176

Microfinance Institution) in Kenya. This is attributed to a low level of education. CMA (2018) has also identified that MFI in Kenya suffers from constraints that lower their resilience to risk and prevent them from developing an efficient credit policy. This, therefore, demonstrates the influence of financial literacy on loan performance. Wanjohi cites a lack of financial skills as a major challenge on loan administration among the DTMFI in Kenya.

Greenspan (2017) argues that financial literacy helps to inculcate individuals with the financial knowledge necessary to create household budgets, initiate savings plans, and make strategic investment decisions. Proper application of that knowledge helps investors to meet their financial obligations through wise planning, and resource allocation so as to derive maximum utility.

Tuyisenge, Mugambi, and Kemirembe (2016) carried out a study on the effect of financial literacy on loan repayment among small and medium enterprises in Rwanda and they concluded that $81 \%$ of the clients agreed that planning skills contributed greatly to loan repayment. Moreover, a study carried out on business management and bookkeeping showed similar results (Nieman \& Bennet, 2016). Indeed, the study showed that entrepreneurs who did not delay repaying loans $85.7 \%$ had bookkeeping literacy while only $14.3 \%$ of the respondents, who did not have bookkeeping literacy delayed repaying their loans. In much the same way, a study on the impact of microfinance on small and medium enterprises also showed that debt management literacy had a great impact on loan repayment (Idowu, 2017).

However, researchers like Kariuki and Wanjiku (2015) conducted a study on financial literacy and loan repayment and concluded that there is a negative relationship between all the constructs of financial literacy and loan repayment of ECLOF (Ecumenical Loan Fund) Kenya clients. Moreover, Kariuki and Wanjiku conducted a study on financial literacy and loan repayment and they concluded that there is a negative relationship between all the constructs of financial literacy and loan repayment of ECLOF Kenya clients. Furthermore, Barua and Sane (2016) found no relationship between financial literacy and loan repayment.

This study will try to investigate the effects of financial literacy on loan repayment for small and medium entrepreneurs in Umurenge SACCO. Could financial literacy help Rwandan small and medium entrepreneurs-some of them are financial illiterate-to repay the loan received from SACCOs? In Rwanda, most of the Rwandan customers of Umurenge SACCOs are not assumed to be financially literate. Specifically, for customers of Umurenge SACCOs in Nyamasheke District like in many other Districts, there might be often lack of information about how to get a loan, how to manage it, how to save and what to save and lack the necessary collateral to obtain one or face discriminatory law or practices related to finance and credit. Or Lack of financial literacy can act as a barrier to saving: if people do not manage their money well they may not have enough left to save after day-to-day expenses, or may accumulate debt they cannot repay. In this regard, it is not surprising that without sufficient financial knowledge; customers of Umurenge SACCOs even might earn a negative return on their capital and of course unable to repay their loan.

The Fin Cap survey (2017) suggests that Rwandans lack a complete set of knowledge, skills, and self-efficacy to be fully financially capable. Furthermore, Data from the 2017 Financial Capabilities Survey (Fin Cap Survey) suggests the following key findings with respect to 


\section{International Journal of Social Sciences and Management Review}

Rwandans' financial capability around cash flow management, planning for the future, and experience with financial services. Therefore, this study was designed to assess deeply the influence of financial literacy on loan repayment among small and medium entrepreneurs in Rwandan SACCOs.

\subsection{PROBLEM STATEMENT}

In Rwanda, at the end of 2007, in the banking sector, there was the liquidation of 9 microfinance which went bankrupt whereby repayment becomes a big challenge for the National Bank of Rwanda (BNR) which in turn promised to pay but paid half of the lost deposits (BNR, 2008); From the year 2009 SACCOs were created at each administrative sector they are always struggling to strengthen their credit management system in order to clean up a bad reputation from previous microfinance. In 2017, the rate of non-performing loans (NPL) for the entire microfinance sector was $8 \%$ including Umurenge SACCOs which was 12.3 as per June 2017 more than 5\% benchmark ratio (BNR, 2018). The NPL affect the financial performance of banks as well as MFIs. Some of the factors, which are a result of this NPL are among other things, poor savings culture and individualism, little education/sensitization of the population, financial illiteracy and bad reputation of SACCOs and MFIs.

Despite the efforts made by SACCOs to increase the loan, have the loans repaid as scheduled without default there is a steady increase in the default rate and a slowdown in the loan repayment by borrowers (BNR, 2018). This trend may cause SACCOs to lack funds to issue to their clients and ultimately close down. Financial literacy is one of the ways which may assist these people to minimize the default rate. This would be done through seminars and training. Financial literacy means the ability to make an informed judgments without fear (Bumcrot et al., 2017).

Several types of research such as those done by mungai(2017), Giné, Menand, Townsend \& Vickery (2016), Cohen \& Young (2017) found the financial literacy is an important determinant of loan repayment contrary to those of Barua and Sane (2018) who found no relationship. In fact, there is mixed evidence as far as financial literacy and loan repayment is concerned. In Rwanda, studies on financial literacy and loan repayment are scanty with only Tuyisenge et all. (2015) conducted the study on the role of financial literacy on loan repayment in Rwanda focusing on banks, not Umurenge SACCOs. The researcher's main purpose was therefore to provide a systematic analysis of the correlational influence of financial literacy on the performance of SMEs in Rwandan SACCOs in line with loan repayment.

\subsection{Objectives of the study}

1. To determine how bookkeeping literacy influences loan repayment of SMEs within SACCOs.

2. To examine how budgeting literacy affects loan repayment of SMEs within SACCOs.

3. To assess how debt management literacy influences loan repayment of SMEs within SACCOs. 


\section{International Journal of Social Sciences and Management Review}

\section{Research questions}

1. How does bookkeeping literacy influence loan repayment of SMEs within SACCOs?

2. To what extent budgeting literacy affect loan repayment of SMEs within SACCOs?

3. How do debt management literacy influence loan repayment of SMEs within SACCOs?

\subsection{LITERATURE REVIEW}

\subsection{Definition of key concepts}

\subsection{SACCOs:}

According to Todaro P.M (2000), SACCOs are cooperative financial organizations owned and operated by and for their members according to democratic principles for the purpose of encouraging savings and using pooled funds to extend loans to members at reasonable rates of interest and providing financial services to enable members to improve their economic and social wellbeing.

\subsection{Financial literacy}

Financial literacy is the education and understanding of knowing how money is made, spent, and saved, as well as the skills and ability to use financial resources to make decisions.

\subsection{Microcredit}

Microcredit could be defined as the supply of small loans to very poor people for selfemployment projects that generate income, allowing them to care for themselves and their families (Grameen Bank, 2002).

\subsection{Loan repayment}

Under the terms of a loan, repayment can have different schedules and requirements. For example, a loan may be amortized over a specific period of time, requiring regular repayments. The repayments would be divided between the interest (i.e. the interest on the outstanding loan amount) and the principal repayment (i.e. the remaining amount of the periodic payment that is used to reduce the outstanding loan amount). At the same time, a loan term may be amortized over a longer period of time than the due date on the loan. In this case, a loan will require a "balloon repayment" (i.e. the amount of principal not yet repaid will be due in full at the end of the term). In either case, all payments on the loan are called repayments.

\subsection{Theoretical review}

This section focuses on reviewing the literature relevant to factors affecting the financial performance of listed firms on RSE such as leverage related theory i.e. pecking order theory, liquidity related theory, i.e. cost trade-off theory, firm size and corporate social 


\title{
International Journal of Social Sciences and Management Review
}

\author{
Volume: 04, Issue: 04 "July - August 2021"
}

ISSN 2582-0176

responsibilities. This provides profound insight into the topic and facilitates the interpretation of the findings. The source of this literature has been academic journals, the internet, newspapers and magazines, newsletters and reports of specific institutions.

\subsection{Social Learning Theory}

Bandura and Ross (1961) posit that social learning theory illustrates how social factors such as sources of information \& financial advice shape a person's behaviour. The financial attitudes and values people have about money come from their environment. The effects of social interactions on individual behaviour have been modelled, tested and applied to a wide variety of situations (Bandura, 1977).

According to this theory, investors are likely to make investment decisions based on the information available in the market, if investors have information about an investment that is likely to generate higher returns in future, investors are more likely to invest in such an investment to accrue higher returns in future (Goel \& Dolan, 2003). The proponents of this theory, the behavioural theorists believed that learning led to a permanent change in behaviour, observational learning demonstrates that people can learn new information without demonstrating new behaviours, especially when considering making financial decisions (Glaeser \& Scheinkman, 2003).

\subsection{SACCOs in Rwanda}

Despite the existence of decades of informal finance grassroots organizations such as the tontines, microfinance started with the creation of the Union des Banques Populaires (UBPR) in 1975. Since then, the microfinance market has followed different phases in its evolution (Association of Microfinance Institutions in Rwanda (AMIR,2010). The Government of Rwanda established Umurenge Saving and Credit Cooperative (SACCO) policy which aimed to encourage the population to form a SACCO at each administrative Sector. The main objective of Umurenge SACCO was to enable the poor people in the rural areas to access financial services and more particularly microfinance services and to fight against exclusion from banking activities. Although Rwanda has made a tremendous steps in microfinance, it cannot escape from challenges. The growth of Rwanda's microfinance industry is impeded by thousands of borrowers who have failed to service their loans, contributing to the high percentages of non-performing loan portfolios seen in Rwanda's MFIs (MINECOFIN, 2010). Research has shown that the poor levels of loan repayment are due to the clients diverting loan funds to meet their personal needs instead of using them for the proposed investment, hampering the ability of MFIs to perform well.

From the review of the studies, the effect of financial literacy on loan repayment is fundamental in any country. This is because loans are very fundamental for the growth of financial sector and hitches in form of defaults in repayment may heavily affect financial stability since the financial institutions may run out of cash to give to the clients and this affects entire economic performance. Some of the literatures however find no relationship between financial literacy and loan repayment. Studies however are very scanty in Rwanda regarding the effects of financial literacy on loan repayment. A deep investigation is therefore necessary on the correlational influence between financial literacy and loan repayment in the 


\section{International Journal of Social Sciences and Management Review}

Rwandan context since micro-financial sector performance forms a major pillar in the economic development of a country.

\subsection{RESEARCH METHODOLOGY}

\subsection{Research approaches}

This research has two approaches including quantitative and qualitative.

- Quantitative approaches: This research work is qualified to be of quantitative study because, during the study, numerical was used, collected and analyzed.

- Qualitative approach: IT was also qualified by more subjective in nature than quantitative and involves examining and reflecting on the less tangible aspects of a research subject, e.g. values, attitudes, perception.

\subsection{Research Design}

This study was descriptive in nature. According to Gay et al, (2006), descriptive research determines and reports the way things are; it involves collecting numerical data to answer questions about the current status of the subject of the study. The research design fits the present study, for it helped to assess SMEs that work with SACCOs as regards financial literacy and loan repayment.

\subsection{Target population}

Peter ODERA (2006) defined population as all members or elements, be it human beings, animals, trees, objects, events of a well-defined group. That is, Population means all the elements in a well-defined set of values. The population of this study was made by all SMEs working with Kanjonjo SACCO in Nyamasheke district which takes the small business as a source of their income. This means different small business dealers were in a number of 130 out of 7,470 members of this SACCO operation in Nyamsheke district, (Kanjongo SACCO Report, 2018).

\subsection{Sampling procedures}

The researcher used the census to select the respondents. This design allows all subsets of the targeted population to be considered as samples in their entirety (Hoyle, R. H., 1999). which means that all SMEs dealers who are 130 make the total sample.

\subsection{Data instruments and data collection process}

Data for this research were collected through documentary sources, electronic search, observation, and questionnaires. The mentioned instruments were used in collecting two types of data including; primary data and secondary data. While carrying out this research, each respondent was provided with a questionnaire and responded to the questions by giving his/her own ideas or argument to know information about how microfinance contributed in alleviating poverty; while the interview guide used in order to find out what the respondents do know, think or feel about some things asked. The research begins by studying documents, 


\section{International Journal of Social Sciences and Management Review}

the review of related literature. The reason for this is mainly is to find out what has been done in a given area and plan the research in such a way that it contributes to the present state of knowledge. The study of documents becomes a method of data collection if the research is mainly based on the available documents.

\subsection{ANALYSIS}

\subsection{Demographic Profile of Respondents}

\subsection{Gender of respondents}

Data about the Gender of the respondents were as follows:

Table 1: Gender of respondents

\begin{tabular}{|l|l|l|l|c|}
\hline \multicolumn{2}{|l|}{ Gender of respondent } & & \\
\hline & & Frequency & Valid Percent & Cumulative Percent \\
\hline Valid & Male & 55 & 42.3 & 42.3 \\
\hline & Female & 75 & 57.7 & 100.0 \\
\hline & Total & 130 & 100.0 & \\
\hline
\end{tabular}

Source: researcher, 2019

From the table above, majority of small entrepreneurs who took loan from SACCOs are female with $57.7 \%$. Male entrepreneurs are $42.3 \%$.

\subsection{Age group of respondents}

Data about age group of the respondents were as follows:

Table 2: Age group of Respondents

\begin{tabular}{|l|l|l|l|c|}
\hline \multicolumn{2}{|c|}{ Age Group of respondents } & & \\
\hline & & Frequency & $\begin{array}{l}\text { Valid } \\
\text { Percent }\end{array}$ & Cumulative Percent \\
\hline Valid & $20-25$ & 4 & 3 & 3 \\
\hline & $26-30$ & 14 & 11 & 14 \\
\hline & $31-35$ & 52 & 40 & 54 \\
\hline & $36-40$ & 33 & 25 & 79 \\
\hline & Above 40 & 27 & 21 & 100 \\
\hline & Total & 130 & 100.0 & \\
\hline
\end{tabular}




\section{International Journal of Social Sciences and Management Review}

Volume: 04, Issue: 04 "July - August 2021"

ISSN 2582-0176

Source: researcher, 2019

Most of the small entrepreneurs who took loans are aged between 31-35 at 40\% followed by $36-40$ at around 25\%, above 40 at around 21\%, 26-30 at around 11\% and lastly 20-25 at 3\%.

\subsection{Level of education}

Small entrepreneurs with diplomas and bachelors take the greatest portion with $43.8 \%$ and $30 \%$ respectively. Certificate holders account for $22.3 \%$ while Master holders account for $3.8 \%$. There was no $\mathrm{PhD}$ holder and more among the respondents.

Table 3: Education level of respondent

\begin{tabular}{|c|l|l|c|}
\hline & Frequency & $\begin{array}{l}\text { Valid } \\
\text { Percent }\end{array}$ & $\begin{array}{c}\text { Cumulative } \\
\text { Percent }\end{array}$ \\
\hline Valid Certificate & 29 & 22.3 & 22.3 \\
\hline Diploma & 57 & 43.8 & 66.2 \\
\hline Bachelor's Degree & 39 & 30.0 & 96.2 \\
\hline Master's degree & 5 & 3.8 & 100.0 \\
\hline Total & 130 & 100.0 & \\
\hline
\end{tabular}

Source: researcher, 2019

\subsection{Duration of being a customer of Umurenge SACCO” Kanjongo SACCO”}

From table 4 here below, it's evident that most of the entrepreneurs who took loans have been customers of Umurenge SACCOs for between 3-4 years. These customers form $50 \%$ of the total respondents. $20.8 \%$ of the respondents have been in the SACCOs for 1-2 years, $17.7 \%$ have been customers for less than a year while $11.5 \%$ have spent less than a year in the SACCOs.

Table 4: Duration of being a customer of Umurenge SACCO

\begin{tabular}{|l|l|l|l|c|}
\hline & & $\begin{array}{l}\text { Frequenc } \\
\text { y }\end{array}$ & $\begin{array}{l}\text { Valid } \\
\text { Percent }\end{array}$ & Cumulative Percent \\
\hline Valid & Less than 1 year & 23 & 17.7 & 17.7 \\
\hline & $1-2$ Years & 27 & 20.8 & 38.5 \\
\hline & 3-4 Years & 65 & 50.0 & 88.5 \\
\hline & 5 years and above & 15 & 11.5 & 100.0 \\
\hline Total & & 130 & 100.0 & \\
\hline
\end{tabular}

Source: researcher, 2019 


\section{International Journal of Social Sciences and Management Review}

Volume: 04, Issue: 04 "July - August 2021"

ISSN 2582-0176

\subsection{FINANCIAL LITERACY TRAINING}

The researcher asked the respondents whether they SACCO has organized any form of financial literacy training. The findings indicate that $90 \%$ of the respondents agreed that the SACCOs have organized financial literacy training while $10 \%$ did not agree.

Table 5: Financial literacy training

\begin{tabular}{|c|l|l|l|}
\hline & Frequency & Valid Percent & Cumulative Percent \\
\hline Valid Yes & 117 & 90.0 & 90.0 \\
\hline No & 13 & 10.0 & 100.0 \\
\hline Total & 130 & 100.0 & \\
\hline
\end{tabular}

Source: researcher, 2019

\subsection{FINANCIAL LITERACY AND LOAN REPAYMENT}

The researcher assessed the respondents on their financial literacy skills which included bookkeeping skills, budgeting skills and debt management skills and how it has affected his/her loan repayment. The results are broken down for each variable based on descriptive statistics and correlation analysis.

\subsection{Bookkeeping literacy and loan repayment}

The respondents were asked the extent to which they possess various bookkeeping skills. The scale of measurement was 1 . Very great extent 2. Great extent 3. Moderate 4. Low extent 5. Very low extent.

Table 6 in the next passage shows that most respondents possess to a moderate extent and too a low extent the bookkeeping skills since the two have relatively higher percentages for all the bookkeeping skills tested. Most respondents possess to moderate extent knowledge on creditors and debtors management skills $(45.8 \%)$ while knowledge on preparation of financial statements $(32 \%)$ is possessed to a moderate extent by the least respondents. Very few respondents possess to a very great extent bookkeeping skills.

Table 6: Possession of book-keeping skills

\begin{tabular}{|l|l|l|l|l|l|}
\hline Statement & $\begin{array}{l}\text { Very } \\
\text { Great } \\
\text { Extent }\end{array}$ & $\begin{array}{l}\text { Great } \\
\text { extent }\end{array}$ & $\begin{array}{l}\text { Moderate } \\
\text { extent }\end{array}$ & $\begin{array}{l}\text { Low } \\
\text { extent }\end{array}$ & $\begin{array}{l}\text { Very low } \\
\text { Extent }\end{array}$ \\
\hline 1. Knowledge on cash flow & $6(5 \%)$ & $17(12.5 \%)$ & $56(43 \%)$ & $31(24 \%)$ & $20(15.5 \%)$ \\
\hline Management & & & & & \\
\hline 2. Knowledge on debtors and & $11(8.5 \%)$ & $23(18 \%)$ & $60(45.8 \%)$ & $29(22.5 \%)$ & $7(5.2 \%)$ \\
\hline
\end{tabular}




\section{International Journal of Social Sciences and Management Review}

Volume: 04, Issue: 04 "July - August 2021"

ISSN 2582-0176

\begin{tabular}{|l|l|l|l|l|l|}
\hline creditors management & & & & & \\
\hline 3. Knowledge on preparation & & $15(11.4 \%)$ & $42(32 \%)$ & $54(41.8 \%)$ & $19(14.8 \%)$ \\
\hline of financial statements & & & & & \\
\hline 4. Knowledge on application & $5(4 \%)$ & $20(15.6 \%)$ & $51(38.9 \%)$ & $46(35 \%)$ & $8(6.5 \%)$ \\
\hline of double entry concept & & & & & \\
\hline $\begin{array}{l}\text { 5. Knowledge on ability to } \\
\text { get }\end{array}$ & $4(3 \%)$ & $24(18.5 \%)$ & $57(43.5 \%)$ & $18(13.5 \%)$ & $27(21.5 \%)$ \\
\hline $\begin{array}{l}\text { accurate financial } \\
\text { information }\end{array}$ & & & & & \\
\hline
\end{tabular}

Source: researcher, 2019

\subsection{The extent to which bookkeeping skills has affected loan repayment behaviour}

From table 7 below, most respondents agreed to a moderate extent that bookkeeping skills have affected their loan repayment behaviour accounting for $54.6 \%$. $15.4 \%$ agreed to a great extent, $26.9 \%$ to a low extent and $3.1 \%$ to a very great extent.

Table 7: Extent to which bookkeeping skills affected loan repayment the extent to which bookkeeping skills has affected loan repayment

\begin{tabular}{|l|l|l|l|l|}
\hline & Frequency & Percent & $\begin{array}{l}\text { Valid } \\
\text { Percent }\end{array}$ & Cumulative Percent \\
\hline Valid Very & & & & \\
\hline Great extent & 4 & 3.1 & 3.1 & 3.1 \\
\hline great extent & 20 & 15.4 & 15.4 & 18.5 \\
\hline moderate extent & 71 & 54.6 & 54.6 & 73.1 \\
\hline low extent & 35 & 26.9 & 26.9 & 100.0 \\
\hline Total & 130 & 100.0 & 100.0 & \\
\hline
\end{tabular}

Source: researcher, 2019

\subsection{Correlation between Book-keeping Skills and Loan repayment}

The correlation coefficient between bookkeeping literacy and loan repayment is 0.742 at a 0.01 significance level as shown in the below table. This implies that there is a high positive association between bookkeeping literacy and loan repayment. Bookkeeping literacy is, therefore, a high predictor of loan repayment backed by the 0.000 significance level.

Table 8: Correlation between bookkeeping skills and loan repayment 


\section{International Journal of Social Sciences and Management Review}

Volume: 04, Issue: 04 “July - August 2021"

ISSN 2582-0176

\begin{tabular}{|c|c|c|c|c|}
\hline & & & Book-keeping & Loan \\
\hline & & & Literacy & Repayment \\
\hline Book & \multicolumn{2}{|c|}{ keeping Pearson } & \multirow[t]{2}{*}{1} & \multirow[t]{2}{*}{$.742^{* *}$} \\
\hline \multirow{4}{*}{$\begin{array}{l}\text { Literac } \\
\mathrm{y}\end{array}$} & & \multirow[t]{2}{*}{ Correlation } & & \\
\hline & & & & \\
\hline & & Sig. (2-tailed) & & .000 \\
\hline & & $\mathrm{N}$ & 130 & 130 \\
\hline \multirow[t]{4}{*}{$\begin{array}{l}\text { Loan } \\
\text { Repayme }\end{array}$} & & Pearson & \multirow[t]{2}{*}{$.742^{* *}$} & \multirow[t]{2}{*}{1} \\
\hline & & Correlation & & \\
\hline & & Sig. (2-tailed) & .000 & \\
\hline & & $\mathrm{N}$ & 130 & 130 \\
\hline
\end{tabular}

**. Correlation is significant at the 0.01 level (2-tailed).

Source: researcher, 2019

\subsection{Budgeting literacy and loan repayment}

The respondents were asked the extent to which they possess various budgeting skills. The scale of measurement was 1 . Very great extent 2. Great extent 3. Moderate 4. Low extent 5. Very low extent.

The results in table 9 in the next passage show that most respondents agreed to a low extent that they pose knowledge on internal audit and forecasting accounting for $43 \%$ and $49.5 \%$ respectively. However, most respondents agreed to a moderate extent that they pose skills in prudence spending, budget control and budget preparation accounting for $45.5 \%, 31 \%$ and $35 \%$ respectively. Averagely most respondents agreed to a moderate extent on budgeting skills while least respondents agreed to a very great extent.

Table 9: Possession of budgeting skills 


\section{International Journal of Social Sciences and Management Review}

Volume: 04, Issue: 04 "July - August 2021"

ISSN 2582-0176

\begin{tabular}{|l|l|l|l|l|l|l|l|}
\hline Statement & & & Very & Great & Moderate & Low & Very low \\
& & & Great & extent & Extent & extent & extent \\
\hline 1.Knowledge & on & budget & $11(8.2 \%)$ & $29(22.4 \%)$ & $46(35 \%)$ & $42(32.5 \%)$ & $2(1.9 \%)$ \\
\hline Preparation & & & & & & & \\
\hline 2.Knowledge on budget control & $7(5 \%)$ & $21(15.7 \%)$ & $40(31 \%)$ & $35(28 \%)$ & $27(20.3 \%)$ \\
\hline 3.Prudence in spending & $7(5 \%)$ & $26(20 \%)$ & $59(45.5 \%)$ & $33(25.5 \%)$ & $5(4 \%)$ \\
\hline 4.Knowledge on ability to do & $3(2 \%)$ & $16(12 \%)$ & $38(29 \%)$ & $64(49.5 \%)$ & $9(7.5 \%)$ \\
\hline Forecasting & & & & & & \\
\hline 5. Knowledge & on & conducting & $7(5 \%)$ & $20(15 \%)$ & $33(25 \%)$ & $55(43 \%)$ & $15(12 \%)$ \\
\hline internal audit & & & & & & & \\
\hline
\end{tabular}

Source: researcher, 2019

The extent to which budgeting skills has affected loan repayment behaviour From table 10 in the next passage, $2.3 \%$ agreed to a very great extent that budgeting skills have affected their loan repayment behaviour, $18.5 \%$ agreed to a great extent, $40 \%$ to a moderate extent, $33.1 \%$ to a low extent and lastly $6.2 \%$ to a very low extent.

Table 10: Extent to which budgeting skills affected loan repayment. The extent to which budgeting has affected loan repayment

\begin{tabular}{|c|c|c|c|c|c|c|}
\hline & & & Frequency & Percent & Valid Percent & Cumulative Percent \\
\hline \multirow[t]{7}{*}{ Valid } & very & great & 3 & 2.3 & 2.3 & 2.3 \\
\hline & extent & & & & & \\
\hline & \multicolumn{2}{|c|}{ great extent } & 24 & 18.5 & 18.5 & 20.8 \\
\hline & \multicolumn{3}{|c|}{ moderate extent 52} & 40.0 & 40.0 & 60.8 \\
\hline & low extent & & 43 & 33.1 & 33.1 & 93.8 \\
\hline & \multicolumn{2}{|c|}{ very low extent } & 8 & 6.2 & 6.2 & 100.0 \\
\hline & Total & & 130 & 100.0 & 100.0 & \\
\hline \multicolumn{3}{|c|}{ Source: researcher, 2019} & & & & \\
\hline
\end{tabular}

Correlation analysis between budgeting literacy and loan repayment

The correlation coefficient between loan repayment and budgeting literacy is 0.644 at a significant level of 0.01. This implies that there is strong positive association between budgeting literacy and loan repayment. 


\section{International Journal of Social Sciences and Management Review}

Volume: 04, Issue: 04 "July - August 2021"

ISSN 2582-0176

Table 11: Correlation between budgeting literacy and loan repayment

\begin{tabular}{|c|c|c|c|}
\hline & & Loan repayment & Budgeting literacy \\
\hline \multirow[t]{4}{*}{ Loan repayment } & Pearson & \multirow{2}{*}{1} & \multirow{2}{*}{$.644^{* *}$} \\
\hline & Correlation & & \\
\hline & Sig. (2-tailed) & & .000 \\
\hline & $\mathrm{N}$ & 130 & 130 \\
\hline Budgeting & Pearson & \multirow{2}{*}{$.644^{* *}$} & \multirow{2}{*}{1} \\
\hline \multirow[t]{3}{*}{ literacy } & Correlation & & \\
\hline & Sig. (2-tailed) & .000 & \\
\hline & $\mathrm{N}$ & 130 & 130 \\
\hline
\end{tabular}

**. Correlation is significant at the 0.01 level (2-tailed).

Source: Researcher, 2019

\subsection{Debt management literacy and loan repayment}

Lastly the researcher assessed the respondents on various debt management skills on a scale of 1 to 5 where 1 . Very great extent 2 . Great extent 3. Moderate 4 . Low extent 5. Very low extent. The findings indicate that most respondents agreed to moderate extent and great extent possession of debt management skills while very few agreed to a very low extent.

Table 12: Possession of debt management skills

\begin{tabular}{|c|c|c|c|c|c|c|c|c|}
\hline \multicolumn{2}{|c|}{ Statement } & & & Very & Great & Moderate & Low & Very \\
\hline & & & & great & extent & Extent & extent & low \\
\hline & & & & extent & & & & extent \\
\hline 1. & \multicolumn{3}{|c|}{ Knowledge on loans and other } & $11(8.6 \%)$ & $30(23 \%)$ & $60(45.8 \%)$ & $29(226 \%)$ & \\
\hline \multicolumn{2}{|c|}{ credit offers } & & & & & & & \\
\hline 2 & \multicolumn{3}{|c|}{ Know ledge on interest rates } & $13(10.4 \%)$ & $33(25 \%)$ & $62(47.5 \%)$ & $22(17.1 \%)$ & \\
\hline 3. & Knowledge & on & loan & $6(5.5 \%)$ & $22(16.4 \%)$ & $57(43.5 \%)$ & $44(33.5 \%)$ & $1(1.1 \%)$ \\
\hline \multicolumn{9}{|c|}{ repayment and effects of default } \\
\hline \multicolumn{2}{|c|}{ 4.Dis cussion with } & & financial & $15(11 \%)$ & $40(31 \%)$ & $64(48.8 \%)$ & $11(9.2 \%)$ & \\
\hline
\end{tabular}

Source: researcher, 2019 


\section{International Journal of Social Sciences and Management Review}

Volume: 04, Issue: 04 "July - August 2021"

ISSN 2582-0176

\subsection{Extent to which debt management skills affect loan repayment behaviour}

The table 13 in the next passage shows that $7.7 \%$ of respondents support to a very great extent that debt management skill affects loan repayment, $23.1 \%$ to a great extent, $50 \%$ to a moderate extent, $15.4 \%$ to a low extent and finally $3.8 \%$ to a very low extent.

Table 13: Extent to which debt management skills affect loan repayment behaviour

\begin{tabular}{|c|c|c|c|c|c|c|}
\hline & & & & & Valid & Cumulative \\
\hline & & & Frequency & Percent & Percent & Percent \\
\hline \multirow[t]{7}{*}{ Valid } & very & great & 10 & 7.7 & 7.7 & 7.7 \\
\hline & extent & & & & & \\
\hline & \multicolumn{2}{|c|}{ great extent } & 30 & 23.1 & 23.1 & 30.8 \\
\hline & \multicolumn{2}{|c|}{ moderate extent } & 65 & 50.0 & 50.0 & 80.8 \\
\hline & low extent & & 20 & 15.4 & 15.4 & 96.2 \\
\hline & \multicolumn{2}{|c|}{ very low extent } & 5 & 3.8 & 3.8 & 100.0 \\
\hline & Total & & 130 & 100.0 & 100.0 & \\
\hline \multicolumn{3}{|c|}{ Source: researcher, 2019} & & & & \\
\hline
\end{tabular}

\subsection{Correlation between debt management literacy and loan repayment.}

The correlation coefficient between debt management literacy and loan repayment is 0.761 showing a strong association between the two variables.at 0.01 significance level.

Table 14: Correlation between debt management literacy and loan repayment

\begin{tabular}{|c|c|c|c|c|}
\hline & & & $\begin{array}{l}\text { Loan } \\
\text { repayment }\end{array}$ & $\begin{array}{l}\text { Debt managemen } \\
\text { literacy }\end{array}$ \\
\hline \multicolumn{2}{|c|}{ Loan repayment } & Pearson & \multirow[b]{2}{*}{1} & \multirow{2}{*}{$.761^{* *}$} \\
\hline & & Correlation & & \\
\hline & & Sig. (2-tailed) & & .000 \\
\hline & & $\mathrm{N}$ & 130 & 130 \\
\hline Debt & \multicolumn{2}{|c|}{ management Pearson } & \multirow{2}{*}{$.761^{* *}$} & \multirow[b]{2}{*}{1} \\
\hline \multirow[t]{3}{*}{ literacy } & & Correlation & & \\
\hline & & Sig. (2-tailed) & .000 & \\
\hline & & $\mathrm{N}$ & 130 & 130 \\
\hline
\end{tabular}




\section{International Journal of Social Sciences and Management Review}

**. Correlation is significant at the 0.01 level (2-tailed).

Source: researcher, 2019

\subsection{REGRESSION ANALYSIS}

The correlation analysis tells us the degree and direction of association between two variables but it does not give the magnitude of change of dependent variable due to a change in an independent variable. Regression analysis therefore tells us the direction and magnitude of change of dependent variable due to a unit change in independent variable. The dependent variable in this study is Loan repayment while independent variables are book keeping literacy, budgeting literacy and debt management literacy. The researcher employed regression analysis approach to study the magnitude of change of loan repayment due to a unit change in book keeping literacy, budgeting literacy and debt management literacy. The model summary results in table 4.15 indicate that the value of $\mathrm{R}$ squared is 0.772 which is equivalent to $77.2 \%$. The significance value of 0.000 in the ANOVA table 16 indicates that the model fit is a good predictor of the variables under study. The coefficients of the independent variables are shown in table 4.17 which shows that $\beta 0, \beta 1, \beta 2$ and $\beta 3$ are 0.016 , $0.599,0.092$ and 0.245 respectively.

Hence the model adopted for this study can be fitted as, $\quad=0.016+0.5991+0.0922+$ 0.245 .

Table 15: Model summary

\begin{tabular}{|l|l|l|l|l|}
\hline & & & Adjusted & R Std. Error of \\
\hline Model R & R Square & Square & the Estimate \\
\hline 1 & $.879^{\mathrm{a}}$ & .772 & .767 & .38093 \\
\hline
\end{tabular}

a. Predictors: (Constant), debt management literacy, budgeting literacy, book keeping literacy

Table 16: ANOVA

ANOVA $^{\mathrm{b}}$

\begin{tabular}{|l|l|l|l|l|l|l|}
\hline & & Sum & of & & & \\
\hline Model & & Squares & Df & Mean Square F & Sig. \\
\hline 1 & Regression & 61.993 & 3 & 20.664 & 142.403 & $.000^{\mathrm{a}}$ \\
\hline & Residual & 18.284 & 126 & .145 & & \\
\hline & Total & 80.277 & 129 & & & \\
\hline
\end{tabular}

a. Predictors: (Constant), debt management literacy, budgeting literacy, book keeping literacy

b. Dependent Variable: loan repayment 


\section{International Journal of Social Sciences and Management Review}

Volume: 04, Issue: 04 "July - August 2021"

ISSN 2582-0176

\begin{tabular}{|c|c|c|c|c|c|c|c|}
\hline \multicolumn{8}{|c|}{ Table 17: Model Coefficients } \\
\hline \multicolumn{2}{|c|}{ Coefficients } & & & & & & \\
\hline & & & \multicolumn{2}{|c|}{ Unstandardized } & Standardized & & \\
\hline & & & Coefficients & & Coefficients & & \\
\hline Model & & & $\mathrm{B}$ & Std. Error & Beta & $\mathrm{t}$ & Sig. \\
\hline \multirow[t]{5}{*}{1} & \multicolumn{2}{|c|}{ (Constant) } & .016 & .145 & & 109 & .003 \\
\hline & \multicolumn{2}{|c|}{ Book keeping literacy } & 599 & .080 & .562 & 7.510 & .000 \\
\hline & \multicolumn{2}{|c|}{ Budgeting literacy } & .092 & .050 & .110 & 1.865 & .045 \\
\hline & Debt & managem ent & 245 & .052 & .293 & 4.669 & .000 \\
\hline & literacy & & & & & & \\
\hline
\end{tabular}

a. Dependent Variable: loan repayment

\subsection{DISCUSSIONS}

The study sought to assess the influence of financial literacy factors on loan repayment among small and medium entrepreneurs of MFIs case of KANJONGO Umurenge SACCO. The study focused on book keeping literacy, budgeting literacy and debt management literacy as the main categories of financial literacy.

\subsection{Influence of book keeping literacy on loan repayment of SMEs within SACCOs}

The study found a positive significant effect of book keeping literacy on loan repayment among small and medium entrepreneurs in MFIs. Most respondents agreed to a moderate extent that book keeping skills has influenced their loan repayment behavior. The correlation analysis results show that the correlation coefficient between book keeping skills and loan repayment is 0.742 with sig value of 0.000 . This suggests that book keeping literacy has a strong positive association with loan repayment. The regression coefficients result further indicate that the coefficient of book keeping literacy is 0.599 which implies that if book keeping literacy increase by one unit, the performance of SACCOs in terms of loan repayment will increase by 0.599 units and vice versa. Therefore, there is a strong positive significant relationship between book keeping literacy and loan repayment. These findings are similar to the ones of Tuyisenge (2015) who found a positive significant effect of book keeping literacy on loan repayment in Rwanda but are against the findings of Kariuki and Wanjiku (2015) who found that all the facets of financial literacy do not have any significant influence on loan repayment.

\subsection{Influence of Budgeting literacy in loan repayment of SMEs within SACCOs}

The second specific objective of this study was to determine the influence of budgeting literacy on loan repayment among small medium entrepreneurs. Most of the respondents 


\title{
International Journal of Social Sciences and Management Review
}

\author{
Volume: 04, Issue: 04 "July - August 2021"
}

ISSN 2582-0176

agreed to a moderate extent that the budgeting literacy skills have influenced their loan repayment pattern. The correlation coefficient of 0.644 between budgeting literacy and loan repayment with sig value of 0.000 indicates a strong significant positive association between budgeting literacy and loan repayment among small medium entrepreneurs. This further suggests that when small medium entrepreneurs gain budgeting skills their loan repayment pattern improves. The coefficient of regression for budgeting literacy was found to be 0.092 with a significance of 0.045 which is less than 0.05.this implies that a one unit change in budgeting skills brings a 0.092 change in loan repayment in the same direction. These results are similar to those of Ongesa et al.(2014) who found positive significant relationship between budgeting skills and loan repayment among small medium entrepreneurs in Ngara, Nairobi County. However the study findings go against the findings of Kariuki and Wanjiku (2015).

\subsection{Influence of debt management literacy on loan repayment of SMES within SACCOs}

The last specific objective of this study was to determine the influence of Debt management literacy on loan repayment among SMEs. The findings indicated a strong positive relationship between the two. The correlation coefficient between debt management and loan repayment was found to be 0.761 at a signicance level of 0 . 000.this indicates a strong positive association between debt management literacy and loan repayment among SMEs. The regression analysis results further indicate that the coefficient of debt management is 0.245 with a significance of 0 . 000.this means that keeping other factors constant, a unit increase in debt management literacy leads to a $24.5 \%$ increase in loan repayment and vice versa. These results are similar to the ones of Tuyisenge (2015) and Siekei (2013) who both found significant effect of debt management on loan repayment studies being conducted in Rwanda and Nigeria respectively.

\subsection{SUMMARY OF FINDINGS}

Out of 178 questionnaires which were issued to the small entrepreneurs, 130 were returned. This represented 73\% return rate. According to Saunders and Thornhill (2011) a response rate for a questionnaire of more than $70 \%$ feedback is suitable for research. The following table shows the results. The second specific objective of this study was to determine the influence of budgeting literacy on loan repayment among small medium entrepreneurs. Most of the respondents agreed to a moderate extent that the budgeting literacy skills have influenced their loan repayment pattern. The correlation coefficient of 0.644 between budgeting literacy and loan repayment with sig value of 0.000 indicates a strong significant positive association between budgeting literacy and loan repayment among small medium entrepreneurs. This further suggests that when small medium entrepreneurs gain budgeting skills their loan repayment pattern improves. The coefficient of regression for budgeting literacy was found to be 0.092 with a significance of 0.045 which is less than 0.05 . this implies that a one unit change in budgeting skills brings a 0.092 change in loan repayment in the same direction. These results are similar to those of Ongesa et al.(2014) who found positive significant relationship between budgeting skills and loan repayment among small medium entrepreneurs in Ngara, Nairobi County. However, the study findings go against the findings of Kariuki and Wanjiku (2015). 


\title{
International Journal of Social Sciences and Management Review
}

\author{
Volume: 04, Issue: 04 "July - August 2021"
}

ISSN 2582-0176

\subsection{CONCLUSION}

First, there is a strong positive correlation between book keeping literacy and loan repayment of SMEs within SACCOs. When SMEs possess book keeping skills there is likelihood that their loan repayment pattern will change for the better, in other words they will be able to repay their loan on time without default.

Secondly there is close relationship between budgeting literacy and loan repayment of SMEs within SACCOs. Budgeting literacy improves the ability of SMEs to pay loan on time without default since they are able to do forecasting and internal audit to identify errors in their books of account hence enabling them to make necessary changes in good time.

Last but not least, debt management literacy is the most crucial factor in enhancing SMEs ability to repay loans from SACCOs. There is a strong positive relationship between the two. When SMEs have debt management literacy, they are able to assess the interest rates charged on various loans, they are able to be aware of the results of default in paying loans and also able to discuss with financial providers in case he/she undergo financial difficulty hence not able to service loan on time. These skills enable the entrepreneur to take caution and try all the best not to fall in to trap of defaulting in payment.

Lastly the study generally finds significant relationship between financial literacy and loan repayment of SMEs within SACCOs. Financial literacy is very important for any entrepreneur who wants to grow the business through loan financing since he/she will be able to have easy time in servicing the loan.

\subsection{RECOMMENDATIONS}

Based on the results of this study, the researcher came up with the following recommendations to the SACCOS's management and members.

First, the SACCOs should initiate more financial training platforms to the members to enable them possess relevant financial management skills to grow their business and other income generating activities hence able to repay their loan on time. Much focus should be shifted to debt management skills since it's the most fundamental factor influencing loan repayment. The members should be made aware of costs of borrowing, penalties of defaulting in payment and need for consultation with the advisors during financial crisis not forgetting book keeping and budgeting skills.

Secondly, members should be on the forefront in attending the financial training in order for them to benefit more on how to manage their finances efficiently, generate profits from their activities and hence able to pay loan on time.

Lastly the government should focus on expending and empowering SACCOs since they also form the key integral part of financial sector development and hence economic growth. The government should carry out periodic auditing of these SACCOs in order to ascertain their performance and offer a helping hand both financially and human resource provision to enhance their growth through problem solving. 


\section{International Journal of Social Sciences and Management Review}

Volume: 04, Issue: 04 "July - August 2021"

ISSN 2582-0176

\section{REFERENCES}

Agarwal, S., Driscoll, J., Gabaix, X \& Laibson, D. (2007). The Age of Reason.Financial Decisions over the Lifecycle. USA: Harvard University.

Ajzen, I. (2008). The theory of planned behavior. Organizational Behavior and Human Decisions Processes, 21, 178-217.

Allon, R. (2012). One Size Strategy for SMEs Does Not Fit All: Entrepreneur-Magazine.

Amisi, S. (2012). The effect of financial literacy on investment decision making by pension fund managers in Kenya, Unpublished MBA Project, University of Nairobi.

Association of Microfinance institutions in Rwanda. (2010). Overview of microfinance industry in Rwanda. Kigali: Author.

Atkinson, A. \& Messy, F. (2005). Assessing financial literacy in 12 countries an OECD Pilot Exercise, Paris: OECD Financial Affairs Division.

Bandura, A. \& Ross, S. A. (1961). Transmission of aggression through the imitation of aggressive models. Journal of Abnormal and Social Psychology, 63,575-582.

Bandura, A. (1977). Social Learning Theory. Englewood Cliffs, NJ: Prentice Hall.

Baron, R. M., \& Kenny, D. A. (1986). The moderator-mediator variable distinction in social psychology research: Conceptual, strategic, and statistical considerations. Journal of Personality and Social Psychology, 51 (2), 1173- 1182

Barua, R., \& Sane, R. (2014). Repayment in microfinance: The role of financial literacy and caste.

Bay, C., Catasús, B., \& Johed, G. (2014). Situating financial literacy. Critical Perspectives on Accounting, 25(1), 36-45. http://doi.org/10.1016/j.cpa.2012.11.011.

Bernheim, D. (1998). Financial Illiteracy, Education and Retirement Saving. In O. Mitchell and S. Schieber (eds.), Living with Defined Contribution Pensions. Philadelphia: University of Pennsylvania Press.

Bumcrot, C., Lin, J., \& Lusardi, A. (2011). The geography of financial literacy. Numeracy, 6 (2).http://doi.org/10.5038/1936-4660.6.2.2.

Calcagno, R., \& Monticone, C. (2015). Financial literacy and the demand for financial advice. Journal of Banking and Finance, 50, 363- 380. http://doi.org/10.1016/j.jbankfin.2014.03.013.

Capital Markets Authority (2010) Capital Raising Opportunities for SMES: The Development of Micro-Cap Securities Markets in Kenya. Nairobi: Capital Markets Authority. 


\section{International Journal of Social Sciences and Management Review}

Volume: 04, Issue: 04 "July - August 2021"

ISSN 2582-0176

Cole, S., \&Sampson, K., Zia, S. (2009). Smart Money: The Effect of Education, Cognitive Ability, and Financial Literacy on Financial Market Participation, Harvard Business School Working Paper 09-071.

Cole, S., Sampson, T. \& Zia, B. (2011). The Demand for Financial Services in Developing Countries. Harvard Business School Working Paper, No. 09-117.

Cohen, M., \& Pamela Y. (2007). Using micro insurance and financial education to protect and accumulate assets, in Caroline O. N. Moser, ed.: Reducing global poverty: The case for assets accumulation (The Brookings Institution, Washington DC).

Cooper, C.R., \& Schindler, P.S.(2006). Business research methods(10 ed.) Boston: McGrawHill. Pauline's Publications.

Emmons(2005). Improving Financial Literacy: analysis of issues and policies. Retrieved from http://www.oecd.org

Evans, J. St. B. T. (2008). Dual-processing accounts of reasoning, judgment and social cognition. Annual Review of Psychology, 59, 255-278.

Falicov, C. (2001). The Cultural Meanings of Money: The Case of Latinos and AngloAmericans, American Behavioral Scientist, 45 (2), 313-328. Fin Capabilities survey (2012). Kigali, Palotti press.

Gatakaa, S. (2010). The relationship between personal financial literacy and lending by commercial banks in Kenya, Unpublished MBA Project, University of Nairobi.

Glaeser, E. \& Scheinkman, J. (2003). Non-Market Interactions. Advances in Economics and Econometrics. Cambridge University Press Paper: Princeton University.

Giné, X., Townsend. R, \& Vickery, J. (2012). "Barriers to Household Risk Management: Evidence From India". American Economic Journal: Applied Economics 5(1): 104-135.

Gravetter, R. \& Forzano, S. (2003). Research Methods for Behavioural Sciences, Belmont:Wardsworth.

Greenspan, A. (2002) Financial Literacy: A Tool for Economic Progress: The Futurist, Vol. $36,(4)$.

Goel, V. \& Dolan R. (2003). Explaining Modulation of Reasoning by Belief. Cognition, 87(1), 11-22.

Hastings, Justine, and Lydia Tejeda-Ashton (2008), "Financial Literacy, Information, and Demand Elasticity: Survey and Experimental Evidence from Mexico," NBER Working Paper n. 14538. 


\section{International Journal of Social Sciences and Management Review}

Volume: 04, Issue: 04 "July - August 2021"

ISSN 2582-0176

Hogarth J \& Hilgert A. (2002), Financial knowledge, experience and learning preferences: Preliminary results from a new survey on financial literacy. Consumer interests annual, 48, 1-7.

Hoyle, R. H. (Ed.). (1999). Statistical strategies for small sample research. Thousand Oaks: Sage Publications.

Idowu F. (2010), Impact of microfinance on small and medium-sized enterprises in Nigeria. International journal of commerce. 12 (2) 11-17.

Jan, S. (2010). Economic evaluation of a combined microfinance and gender training intervention for the prevention of intimate partner violence in rural South Africa." Health Policy and Planning Journal, 23(2),12-19.

Kariuki, J.W. \& Muturi, W. (2015). Effect of financial literacy on loan repayment a case of ecumenical churches loan fund, Kenya. International Journal of Social Science and Information. Vol.3, (2).

Kombo, D., \& Tromp, L. (2009). Proposal and Thesis Writing; An Introduction. Pauline Publications Africa, Nairobi.

Landerretche, T., \& Martínez, W. (2012). similarly find that financial literacy increases savings in private pension plans in Chile. Among the studies that examine the role of financial literacy on bank account ownership.

Lusardi, A., \& Mitchell, O. S. (2011). Financial Literacy and Planning. Implications for Retirement Wellbeing (No. 17078). National Bureau of Economic Research.

Luvavo (2013). Factors Influencing the Repayment of the Youth Enterprise Development fund loan by Youth Groups in Sabatia Constituency. UON Repository.

Ministry of Finance and Economic Planning. (2007). The Impact of Umurenge SACCOs on the Rwandan Financial Sector. Kigali: Author.

Mugenda, O.M, \& Mugenda, A.G. (1999). Research Methods: Quantitative and Qualitative Approaches, Acts Press: Nairobi.

Mugenda,O.,\&Mugenda,A. (2003).Research methods: Quantitative andqualitative approaches. Acts Press: Nairobi.

Mungai, N. W. (2012). Effect of Financial Literacy Programs on The Survival of Women Entrepreneurs in Kawangware, unpublished MBA thesis, Kenyatta University.

Nieman, G., \& Bennet, A. (2006). Business Management: A Value Chain Approach, Pretoria.

Nyamute, W., \& Maina, JKM. (2011). Effect of financial literacy on personal financial mangement practices: a case study of employees of finance and banking institututions ,e $^{\text {, }}$

Available from: 


\section{International Journal of Social Sciences and Management Review}

Volume: 04, Issue: 04 "July - August 2021"

ISSN 2582-0176

http://erepository.uonbi.ac.ke/bitstream/handle/11295/9897/aibuma2011-

submission224.

Oladeebo, J.O., \&Oladeebo, O.E. (2008) Determinants of loan repayment among smallholder farmers in Ogbomoso agricultural zone of Oyo State, Nigeria. Journal of Soc. Science, Vol.17(1): 59-62.

Ongesa et al.(2014). An Assessment of Financial Literacy on Loan Repayment in Ngara,Nairobi County. Research Journal of Finance and Accounting, 5(12),181-192.

Ozmon, H., \& Craver, S. (1999). Philosophical foundations of education. Upper Saddle River, Merrill: New Jersey.

Tustin, D. H. (2010). An impact assessment of a prototype financial literacy flagship programme in a rural south african setting, African Journal of Business Management 4, 1894-1902.

Tuyisenge, W., Mugambi, F., \& Kemirembe, R. (2015). The role of financial literacy on loan repayment. International Journal of Small Business and Entrepreneurship Research, 3(5), 33-66.

Siekei, J. Juma, W., \& Aquilars, K. (2013). An assessment of the role of financial literacy on performance of small and micro enterprises: Case of Equity Group Foundation Training Program on SMES in Njoro district, Kenya.

Wanjohi, A (2011) Kenya Vision 2030 and youth agenda. Kenpro Papers Portal. Available http://www.kenpro.org/tag/sme-sector-in-kenya/ retrieved on 30th July 2015.

\section{APPENDIX 1:}

\section{Research Questionnaire}

Dear respondents, you have been selected to participate in this study. This study is called 'the effects of financial literacy on loan repayment amongst small and medium entrepreneurs of microfinance institutions'. This research is purely for academic purposes. The information provided will be treated with highest confidentiality. Respond by ticking the most appropriate response.

SECTION A: Identification of respondents

Tick the appropriate option

\section{Your gender}

\begin{tabular}{|l|l|}
\hline Male & \\
\hline Female & \\
\hline
\end{tabular}

\section{Your age group:}




\section{International Journal of Social Sciences and Management Review}

Volume: 04, Issue: 04 "July - August 2021"

ISSN 2582-0176

\begin{tabular}{|l|l|l|l|l|}
\hline 20-25 years & 26-30 years & $31-35$ years & $36-40$ years & above 41 years \\
\hline & & & & \\
\hline
\end{tabular}

\section{Your level of education:}

\begin{tabular}{|l|l|l|l|l|}
\hline Certificate & Diploma & $\begin{array}{l}\text { Bachelor's } \\
\text { degree }\end{array}$ & Master degree & $\begin{array}{l}\text { PhD and } \\
\text { more }\end{array}$ \\
\hline & & & & \\
\hline
\end{tabular}

4. How long have you been a customer of Umurenge SACCO "KANJONGO SACCO"?

\begin{tabular}{|l|l|l|l|}
\hline Less than 1 year & $1-2$ years & 3-4 years & Over 5 years. \\
\hline & & & \\
\hline
\end{tabular}

\section{Section B: Specific Questions}

5.0 Has your SACCO organized any financial literacy trainingsprogramme to assist you in your business activities?

\begin{tabular}{|l|l|}
\hline Yes & \\
\hline NO & \\
\hline
\end{tabular}

If yes, which are they?

- Book keeping: Cash flow management, debtors and creditors management, ability to prepare financial statements

- Budget literacy: Ability to prepare budget, ability to control budget, internal audit, prudence in spending, ability to do sales forecasting

- Credit management skills: Knowledge on loans and other credit offers, knowledge on interest rate, knowledge on loan repayment and effects of default, ability to discuss with financial providers during financial crisis

Express your opinion by ticking appropriately as to what extent the financial literacy trainings have had on your loan repayment:

1) Very great extent 2) Great extent 3) Moderate 4) low extent 5) Very low extent

\section{Book-keeping}

\begin{tabular}{|l|l|l|l|l|l|}
\hline Items & 1 & 2 & 3 & 4 & 5 \\
\hline I have understood to manage cash flow & & & & & \\
\hline
\end{tabular}




\section{International Journal of Social Sciences and Management Review}

I have had enough knowledge on debtor and creditors management

I have been able to prepare financial statements

I have been able to employ double entry concept

I have been able to get accurate financial information

\section{Budgeting Literacy}

\begin{tabular}{|l|l|l|l|l|l|}
\hline Items & 1 & 2 & 3 & 4 & 5 \\
\hline I have been able to prepare budget & & & & & \\
\hline I have been able to control budget & & & & & \\
\hline I have had prudence in spending & & & & & \\
\hline I have been able to do forecasting & & & & & \\
\hline I have initiated internal audit & & & \\
\hline
\end{tabular}

\section{Debt management skills}

\begin{tabular}{|l|l|l|l|l|l|}
\hline Items & 1 & 2 & 3 & 4 & 5 \\
\hline I have had Knowledge on loans and other credit offers & & & & & \\
\hline I have had Knowledge about interest rate methods and calculation & & & & & \\
\hline I have had Knowledge on loan repayment and effects of default & & & & \\
\hline $\begin{array}{l}\text { I have been able to discuss with financial providers during business } \\
\text { financial crisis }\end{array}$ & & & & \\
\hline
\end{tabular}

7. Compared to the period before you took the financial literacy training, would you say your loan repayment?

- Has been effective

- Ineffective

- Stayed the same

8. Have you kept any saving in cash for investment or future payment as a result of the knowledge you got from the aforementioned trainings?

\begin{tabular}{|l|l|}
\hline Yes & \\
\hline NO & \\
\hline
\end{tabular}

9. If yes, were you able to repay the loan on schedule before you took the trainings?

\begin{tabular}{|l|l|}
\hline Yes & \\
\hline NO & \\
\hline
\end{tabular}


International Journal of Social Sciences and Management Review

Volume: 04, Issue: 04 "July - August 2021"

10. If no, were you able to repay the loan on schedule after receiving the financial literacy trainings?

\begin{tabular}{|l|l|}
\hline Yes & \\
\hline NO & \\
\hline
\end{tabular}

Thank you for your collaboration. 